\title{
Biotic and abiotic factors influencing attachment strength of blue mussels Mytilus edulis in suspended culture
}

\author{
A. A. Lachance ${ }^{1}$, B. Myrand ${ }^{2}$, R. Tremblay ${ }^{1, *}$, V. Koutitonsky ${ }^{1}$, E. Carrington ${ }^{3}$ \\ ${ }^{1}$ Institut des Sciences de la Mer (ISMER), Université du Québec à Rimouski, 310 allée des Ursulines, Rimouski, \\ Quebec G5L 3A1, Canada \\ ${ }^{2}$ Centre Maricole des Îles de la Madeleine, MAPAQ, 107-125 chemin du Parc, Cap-aux-Meules, Quebec G4T 1B3, Canada \\ ${ }^{3}$ Department of Biology and Friday Harbor Laboratories, University of Washington, 620 University Road, Friday Harbor, \\ Washington 98250, USA
}

\begin{abstract}
Mussels secrete byssal threads regularly to the substratum, and the strength of these threads can fluctuate with time. The present study examined weekly variations in the attachment strength of $2 \mathrm{yr}$ old cultured mussels Mytilus edulis on submerged longlines in a semi-enclosed lagoon from late May to mid-October. Some possible factors influencing attachment strength were investigated: environmental factors (temperature, food availability, wind velocity and hydrodynamic conditions such as current velocity, turbulence and wave height) and reproductive condition were measured concurrently. Attachment strength was measured directly on cultured mussels using a dynamometer. Attachment strength varied 2-fold from summer to fall, a difference related not only to the number of byssal threads but also to their individual strengths. The hierarchical influence of each factor on attachment strength is discussed. Our results suggest that spawning seemed to be correlated with an important decrease $(-32 \%)$ in attachment strength, and that water temperature (negative relationship) and turbulence (positive relationship) were the most important factors explaining the variation in mussel attachment strength. In contrast to previous studies carried out in intertidal zones, no trade-offs were observed between reproduction and attachment strength.
\end{abstract}

KEY WORDS: Mytilus edulis $\cdot$ Attachment strength $\cdot$ Seasonal variation $\cdot$ Byssal threads

\section{INTRODUCTION}

Mussels can attach themselves to solid substrata by producing byssal threads. The byssus, composed of multiple extracellular collagenous byssal threads, is secreted by a gland at the base of the foot. Byssal threads have a limited lifetime (probably 4 to $6 \mathrm{wk}$ for Mytilus edulis; Carrington 2002a, Moeser \& Carrington 2006), and mussels secrete new threads regularly. In most of the studies on attachment strength of mussel byssus, the number of threads is used to characterize attachment strength (more threads = stronger attachment), and single explanatory factors are usually studied by controlled laboratory experiments (Young 1985, Lee et al. 1990, Dolmer \& Svane 1994, Clarke 1999,
Selin \& Vekhova 2004, Alfaro 2005). In other studies, the byssal thread counts have been complemented by a measure of the actual force required to pull the mussel off of its attachment. Such studies have usually been performed in the field on wild mussels attached to rocky shores (Price 1982, Carrington 2002a, Zardi et al. 2007).

A number of factors can influence the attachment strength of mussels. For example, byssal thread production increases with water temperatures ranging from 0 to $25^{\circ} \mathrm{C}$, but is inhibited above $26^{\circ} \mathrm{C}$ (Young 1985, Lee et al. 1990, Selin \& Vekhova 2004). Food availability can also influence attachment strength by decreasing thread production when food is limited (Price 1980, Young 1985, Clarke 1999, Carrington 
2002a). Mussels living in the intertidal zone are also challenged by substrate instability and hydrodynamic forces generated by wave action (Price 1982, Bell \& Denny 1994, Bell \& Gosline 1997, Carrington 2002a, Hunt \& Scheibling 2002), and byssal thread production seems to be influenced by various aspects of water motion, such as current velocity (1-directional water motion; Lee et al. 1990, Dolmer \& Svane 1994, Bell \& Gosline 1997, Alfaro 2005, Moeser et al. 2006) and turbulence (multi-directional water motion; Young 1985). Endogenous factors such as reproductive condition may also be linked to mussel attachment strength (Hawkins \& Bayne 1985, Seed \& Suchanek 1992). Several studies have observed an inverse relationship between reproductive cycle and attachment strength, suggesting that mussels may not always have energy available for byssal thread production (Price 1980, 1982, Carrington 2002a, Zardi et al. 2007). Mussel attachment strength does not just depend on the number of byssal threads produced, but also on the material properties of the threads (Moeser \& Carrington 2006).

Since so many factors can influence mussel attachment strength, it is not surprising to observe seasonal fluctuations of attachment strength in natural populations (Price 1980, 1982, Hunt \& Scheibling 2001, Carrington 2002a). Many of the factors cited above covary naturally, making it difficult to determine which factors are the most important for attachment strength. Nevertheless, several studies of wild mussels living in the intertidal zone suggest the importance of wave action (Price 1980, 1982, Hunt \& Scheibling 2001, Carrington 2002a). Suspension-cultured mussels kept on ropes in the water column in sheltered areas are submitted to different hydrodynamic conditions, where waves, current velocity and turbulence may not have the same influence on attachment strength. As no studies have ever been done on the attachment strength of suspension-cultured mussels, this information is not available.

The main purpose of the present study was to examine the temporal variation in attachment strength for the first time in suspension-cultured mussels in a semienclosed lagoon and to identify explanatory factors, particularly reproduction and environmental conditions. In the Magdalen Islands, loss of mussels by detachment is significant and decreases the productivity of mussel culture farms (Mallet \& Myrand 1995, Bourque \& Myrand 2006). On the east coast of Canada, 2 species of blue mussel are present, Mytilus edulis and $M$. trossulus, but $>98 \%$ of the mussels in lagoons of the Magdalen Islands are M. edulis (Tremblay et al. 1998). The first specific objective was to measure the variability in mussel attachment strength on the suspended culture structures known as sleeves from spring to fall on a weekly basis. This is a more frequent sampling regime than those of previous studies, which were based on monthly samplings. Concurrently, mussel reproductive condition was quantified and the following environmental characteristics were monitored: temperature, food availability, wind velocity and hydrodynamic conditions (current velocity, turbulence and wave height). A hierarchy of these factors was established according to their relationship to mussel attachment strength. A second objective consisted in an evaluation of the strength of individual byssal threads in 2 different periods (summer and fall).

\section{MATERIALS AND METHODS}

A preliminary study was conducted from 25 June to 13 October 2004. This effort guided a more extensive sampling from 24 May to 17 October 2005 that included attachment strength measurement, reproductive condition determination, seston characterization and environmental monitoring of the water column.

Site. Experiments took place in House Harbour lagoon in the Magdalen Islands, Gulf of St. Lawrence, Canada, where blue mussels Mytilus edulis are cultivated (Fig. 1). The maximum depth of House Harbour lagoon as well as at the experimental site is approximately $6 \mathrm{~m}$. The lagoon is connected to the open sea by a relatively narrow channel. The maximum tidal amplitude is only about $0.5 \mathrm{~m}$, tidal current velocities are relatively low $\left(<0.05 \mathrm{~m} \mathrm{~s}^{-1}\right)$, and wind is very

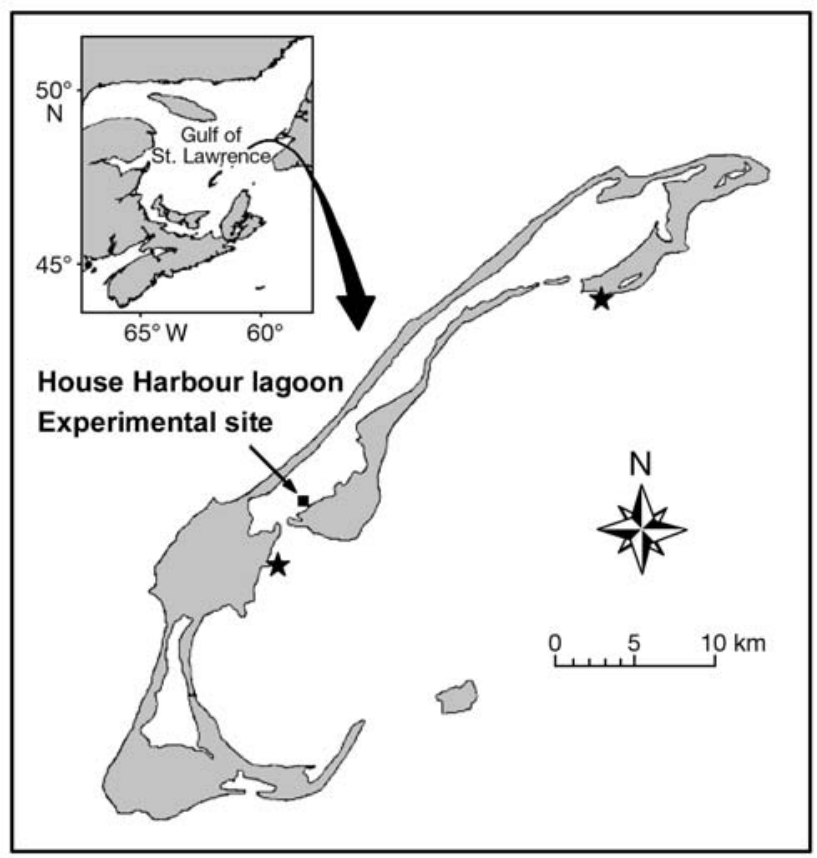

Fig. 1. Location of the experimental site in House Harbour lagoon in the Magdalen Islands. The 2 stars indicate the positions of the tidal gauges 
important to the mixing of the water column in this shallow lagoon (Koutitonsky et al. 2002, Koutitonsky \& Tita 2006).

Attachment strength and reproductive condition. In early May, when mussels are tightly attached to the culture substrate (polypropylene rope), 69 sections of $0.6 \mathrm{~m}$ of the culture substrate holding $2 \mathrm{yr}$ old commercial mussels (approximately $60 \mathrm{~mm}$ shell length) were prepared. These experimental sections (hereafter referred to as 'sleeves') were suspended on a submerged longline kept at about $2 \mathrm{~m}$ from the surface. Every week, 3 sleeves were harvested randomly from the longline, carefully brought back to the laboratory, and held vertically in a flow-through tank supplied with seawater pumped from the lagoon until attachment strength was measured (within $24 \mathrm{~h}$ ).

Attachment strength was measured weekly on 45 mussels (15 mussels sleeve ${ }^{-1}$ ) in 2004 and on 30 mussels $\left(10\right.$ mussels sleeve ${ }^{-1}$ ) in 2005 . The sleeve was first fixed tightly with a net in a horizontal position on a wooden board; sleeves were kept wet during measurements. The chosen mussels were located on the outer surface of the sleeve (thus not overgrown by neighbors) and oriented with their long axis perpendicular to the sleeve (Fig. 2). The net was cut just around the mussel, and a small hole was drilled through the mussel shell. A hook was inserted through the hole and connected to a digital dynamometer (AFG $250 \mathrm{~N} \pm 0.05$ Quantrol; Dillon) fixed on an endless screw stand just above the mussel. The individual mussel was pulled vertically from the sleeve with a small motor running at constant low speed until complete dislodgement of the mussel occurred. The maximum force (measured in Newtons) applied before dislodgement was recorded using the QGraph Quantrol software (Dillon) and represents the attachment strength. Only mussels at the outer surface of the sleeves could be measured due to the impossibility of measuring mussels in the middle without disturbing the mussel assemblage. This method measured the global rather than the self-attachment strength of a

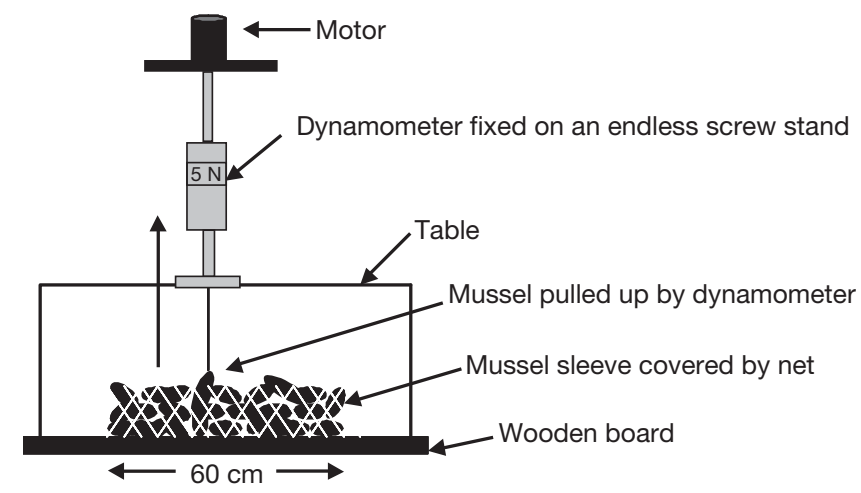

Fig. 2. Diagram of the device used to measure the attachment strength of suspension-cultured mussels with a dynamometer given mussel because the mussels on a sleeve attach their byssal threads to the shells of other mussels. As a result, the experimental mussels were kept attached to the sleeve by their neighbors' threads as well as by their own when tested with the dynamometer. After attachment strength measurement, shell length was measured using a vernier caliper. Because the range of mussel size was small within all the samples (mean length \pm SD: $68.3 \pm 5.0 \mathrm{~mm}, \mathrm{n}=630$ ), no normalization of the attachment strength to mussel size was applied. Each mussel was dissected, and the gonad index was calculated as the dry whole mantle weight $(72 \mathrm{~h}$ at $70^{\circ} \mathrm{C}$ ) divided by the whole body weight (the sum of the dry weights of the mantle and remaining tissues). Indexes related to tissue mass have been found to be good indicators of spawning events, particularly for suspended cultured mussels in Magdalen Island lagoons (Myrand et al. 2000, Lemaire et al. 2006). Mussel gonads also occupy a volume of the visceral mass when mature, and measurements involving only the mantle underestimate reproductive condition. However, as spawning events are mostly synchronized in suspension culture of mussels (Myrand et al. 2000), this underestimation is likely to be constant.

Individual force of byssal threads. An additional 10 mussels were taken randomly from sleeves on 2 different dates in the summer (2 August 2005) and fall (17 October 2005). Mussel byssus was removed carefully from its substrate, thread by thread, at the plaque region of the thread, and the byssus was cut off at the shell margin. The byssus was then dehydrated by air exposure in an open plastic bag until tensile tests were performed (Brazee \& Carrington 2006). The byssus (byssal threads and stem) of each mussel was rehydrated for $30 \mathrm{~min}$ in seawater before testing. The 2 ends of the byssal threads (distal [or disc] region and proximal [or stem] region) were mounted within a pair of grips using cardstock and cyanoacrylate glue. The grips were attached to the mobile crosshead of a tensometer (Instron 5565). Threads were submerged in seawater at $15^{\circ} \mathrm{C}$ and extended $10 \mathrm{~mm} \mathrm{~min}^{-1}$ until failure occurred. Force $( \pm 0.02 \mathrm{~N})$ was recorded every second, and the maximum value was used as the thread strength (Moeser \& Carrington 2006).

Seston characterization. During each weekly sampling, 3 water samples of 21 were taken with a Niskin bottle at the depth of mussel sleeves $(2 \mathrm{~m})$. The seawater was kept in cool conditions in the dark until filtration on the same day through washed and preweighed GF/C filters following the method of Aminot \& Chaussepied (1983) to obtain the total particulate matter (TPM) and the particulate inorganic matter (PIM). The seston component used in the present study was the particulate organic matter (POM), which was calculated by subtracting PIM from TPM. 
Environmental monitoring. To monitor the water column characteristics, an acoustic doppler current profiler (ADCP) Workhorse Sentinel $1200 \mathrm{KHz}$ (RD Instruments) and an acoustic doppler velocimeter (ADV) Vektor $6 \mathrm{MHz}$ (Nortek) were placed near the bottom of House Harbour lagoon next to the experimental longline from 15 June to 19 October 2005. The ADCP measured the current velocity at $30 \mathrm{~cm}$ depth intervals throughout the whole water column every $20 \mathrm{~min}$, but only the current velocity data recorded at the sleeve level were used in the analysis. The ADV probe components consisted of an acoustic transmitter and 3 acoustic receivers measuring water velocity on the $x-, y$ - and $z$-axes at $50 \mathrm{~cm}$ above the bottom surface at $8 \mathrm{~Hz}$. Total turbulence fluctuations $\left(\Delta V_{\Sigma}\right)$ as well as those on the $x(\Delta u), y(\Delta v)$ and $z(\Delta W)$ axes were defined as the standard deviation of $V_{\Sigma}, u, v$ and $W$, respectively, within the ADV sampling period. Furthermore, the ADV measured water temperature every $60 \mathrm{~min}$ and wave height every $20 \mathrm{~min}$ using data recorded during a period of $5 \mathrm{~min}$ at $8 \mathrm{~Hz}$. The wind velocity data were measured by Environment Canada at the local airport, about $1 \mathrm{~km}$ from the experimental site. Two tide gauges (Coastal Leasing Micro Tide $2 \mathrm{~Hz}$ ) recording at $20 \mathrm{~min}$ intervals were placed at 2 different sites (Fig. 1). Tide and current data were used in the calculations of hydrodynamic parameters. For all the water column data, daily mean values were calculated from the hourly values, and weekly means were then determined from the daily mean values. Significant wave height $\left(H_{\mathrm{s}}\right)$ corresponds to the average height of the highest one-third of all waves occurring during a particular time period (Open University 1989) and was used as the wave parameter in analyses. The salinity in the lagoon was not measured due to its stability (28 to 31 ) (Myrand et al. 2000).

Statistical analysis. The sample size was 45 mussels $\mathrm{wk}^{-1}$ in 2004, but was decreased to 30 mussels $\mathrm{wk}^{-1}$ in 2005 following a statistical power analysis. The coefficient of variation was determined for each sampling date with $\mathrm{n}=45$ (15 mussels sleeve ${ }^{-1}$ ) and compared to the coefficient of variation with $\mathrm{n}=30$ (10 mussels sleeve $\mathrm{e}^{-1}$ ). The analysis revealed no significant change in the precision of the results (Statistical Consultation
Services, Hélène Crépeau, Mathematical Department, Laval University, pers. comm.).

All statistical analyses were performed using Systat 11 (Systat Software), and data were log or square-root transformed when necessary to satisfy test conditions. A 2-way hierarchical ANOVA tested for a difference in attachment strength between sampling dates in 2004 and 2005, with date and sleeve (nested factor) as factors. Since we were primarily interested to compare only the differences between successive dates, $t$-tests with sequential Bonferroni correction were deemed more appropriate than a complete multiple post hoc comparison table. A 1-way ANOVA evaluated the temporal variation of organic seston in 2005, and the same multiple planned comparison tests identified specific differences among dates. A $t$-test was used to compare the strength of individual byssal threads between dates.

For the 2004 and 2005 data, simple Pearson correlations were used to evaluate the relation between mussel attachment strength and individual factors. For 2004, these factors were temperature, wind velocity and gonad index; for 2005, they were temperature, turbulence, $H_{\mathrm{s}}$ gonad index, organic seston, current velocity and wind velocity. In addition, for both 2004 and 2005, a forward stepwise multiple regression was used to create a model using the most significant factors of those cited above to explain the variations of the response variable (attachment strength). For the multiple regression with 2004 data, the gonad index was log transformed to linearize the relationship to attachment strength; no collinearity was found between the 3 factors (temperature, wind velocity and gonad index) (coefficient of correlation < 0.462). For the 2005 multiple regression analysis, gonad index, organic seston, turbulence and $H_{\mathrm{s}}$ were log transformed to linearize the relationship between the explanatory factors and the response variable. Collinearity was found between temperature and turbulence, gonad index and wind velocity (coefficients of correlation $=-0.665,-0.645$ and -0.704 , respectively; Table 1). Thus, a second multiple regression analysis was conducted without temperature. This multiple regression analysis was also performed with another probability threshold

Table 1. Pearson correlation matrix with correlation coefficients between all factors in $2005 . H_{\mathrm{s}}$ : significant wave height

\begin{tabular}{|lcrrrrr|}
\hline & Temperature & Turbulence & \multicolumn{1}{c}{$H_{\mathrm{s}}$} & Gonad index & Organic seston & Current velocity \\
\hline Temperature & 1.000 & & & & & \\
Turbulence & -0.665 & 1.000 & & & & \\
$H_{\mathrm{s}}$ & -0.405 & 0.344 & 1.000 & & & \\
Gonad index & -0.645 & 0.313 & 0.120 & 1.000 & & \\
Organic seston & -0.107 & 0.560 & -0.194 & -0.156 & 1.000 & 1.000 \\
Current velocity & -0.024 & -0.085 & 0.048 & 0.182 & -0.068 & -0.235 \\
Wind velocity & -0.704 & 0.472 & 0.101 & 0.408 & 0.010 & 1.000 \\
\hline
\end{tabular}


(0.20 instead of 0.05$)$ to include a second factor in the model (Quinn \& Keough 2002).

The mean attachment strength for a given sampling date was related to the mean of the previous $7 \mathrm{~d}$ of environmental measurements (current velocity, turbulence, temperature, wind velocity, wave height), thereby estimating the environment conditions between the 2 sampling dates. For organic seston and the gonad index, which were sampled less frequently, the measurements from the same sampling date were used. These data forms were used in all analyses and figures showing the relationship between factors and attachment strength.

\section{RESULTS}

\section{4}

In the preliminary 2004 study, attachment strength showed significant variations during the sampling period (Table 2). A decrease in attachment strength was observed at the beginning of the sampling period (from 25 June to 19 July), with a significant difference $\left(t_{88}=3.04, \mathrm{p}=0.003\right)$ between 5 and 12 July (Fig. 3A). Attachment strength was generally low during the summer $($ mean $=22.5 \mathrm{~N}$ between 25 June and 30 August), then increased steadily from the beginning of September to a peak of $42.6 \mathrm{~N}$ in mid-October, the last sampling date (Fig. 3A). The gonad index also showed significant variations during the sampling period (Table 2), but no significant differences between 2 successive dates were revealed with the $t$-tests (Fig. 3B).

Temperature varied between 10.3 and $20.6^{\circ} \mathrm{C}$ during the sampling period, with higher values from mid-July to the end of August, after which it decreased in the fall (Fig. 3C). Wind velocity was relatively constant until the end of August, after which it increased through September until the beginning of October (Fig. 3D).

Table 2. Hierarchical ANOVAs measuring the differences between dates in 2004 for: attachment strength (AS) and gonad index (GI), $\mathrm{n}=644 ; \mathrm{AS}$ and GI were square-root transformed

\begin{tabular}{|lrrrr|}
\hline Source & df & MS & $F$ & \multicolumn{1}{c|}{ p } \\
\hline Attachment strength & & & \\
Date & 14 & 12.069 & 7.946 & $<0.001$ \\
Sleeve (Date) & 30 & 1.519 & 2.060 & 0.001 \\
Error & 599 & 0.737 & & \\
Gonad index & & & & \\
Date & 14 & 0.021 & 2.340 & 0.025 \\
Sleeve (Date) & 30 & 0.009 & 1.560 & 0.030 \\
Error & 599 & 0.006 & & \\
\hline
\end{tabular}

Correlations between each factor (gonad index, temperature and wind velocity) and the attachment strength were revealed by simple Pearson correlations. Only the negative correlation with temperature was significant (Table 3). Gonad index was the second most correlated factor to attachment strength, although not significantly so. A forward stepwise multiple regression analysis was conducted to examine the relative importance of each factor. Temperature was the first factor to be entered into the model, and it explained $52 \%$ of the attachment strength variation. The regression stopped at the second step, after the addition of wind velocity, and the model including these 2 factors explained $61 \%$ of the attachment strength variability (Table 4). More-
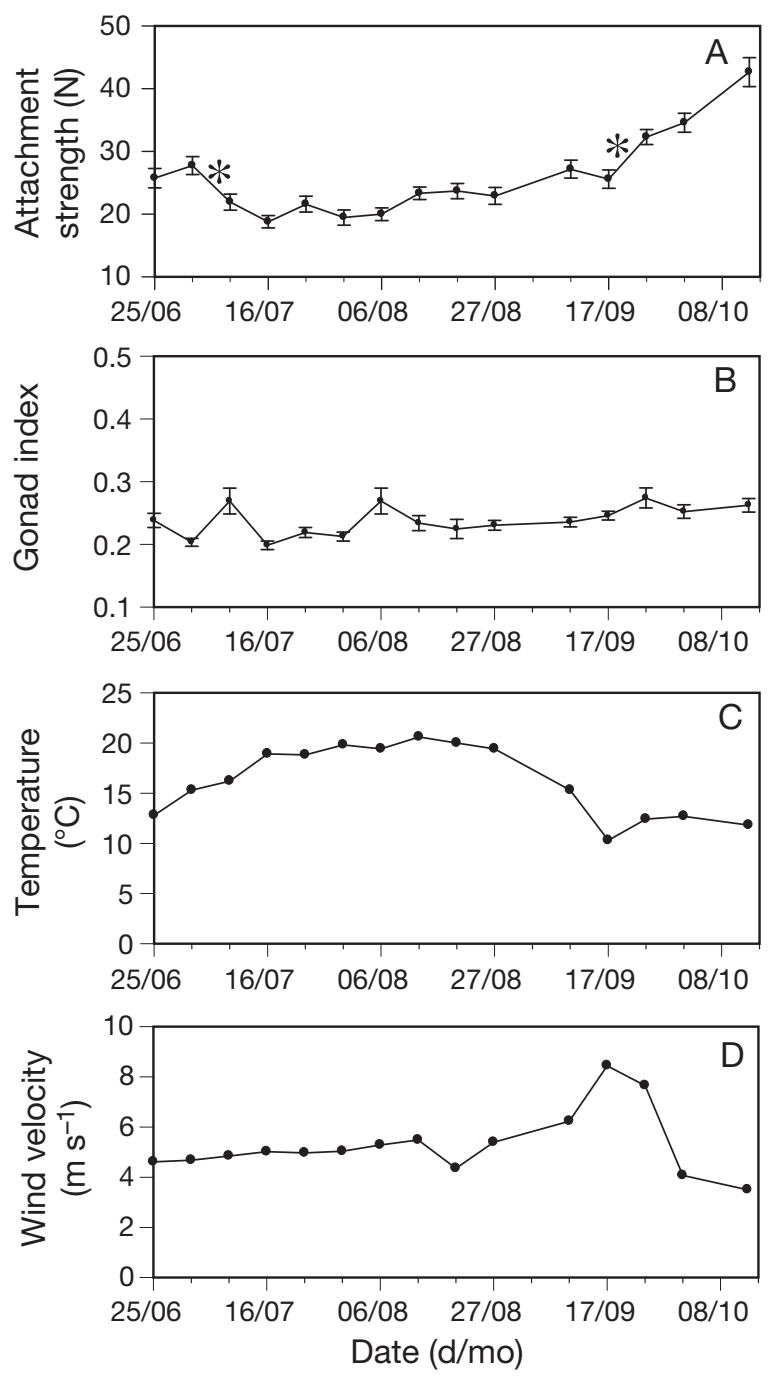

Fig. 3. Mytilus edulis. Weekly values measured from 25 June to 15 October 2004: (A) attachment strength (mean $\pm \mathrm{SE}$ ), (B) gonad index (mantle dry weight [DW] / whole tissue DW; mean $\pm \mathrm{SE}$ ), (C) temperature and (D) wind velocity. An asterisk between 2 successive dates indicates a significant difference revealed by planned comparisons using a $t$-test followed by a sequential Bonferroni correction. N: Newton 
Table 3. Simple Pearson correlations between each explanatory factor and attachment strength in 2004 ( $\mathrm{n}=15)$. $\mathrm{r}^{2}$ : coefficient of determination

\begin{tabular}{|lrc|}
\hline Factor & \multicolumn{1}{c|}{$\mathrm{r}^{2}$} & $\mathrm{p}$ \\
\hline Temperature $\left({ }^{\circ} \mathrm{C}\right)$ & -0.52 & 0.015 \\
Gonad index & 0.20 & 0.545 \\
Wind velocity $\left(\mathrm{m} \mathrm{s}^{-1}\right)$ & -0.03 & 1.000 \\
\hline
\end{tabular}
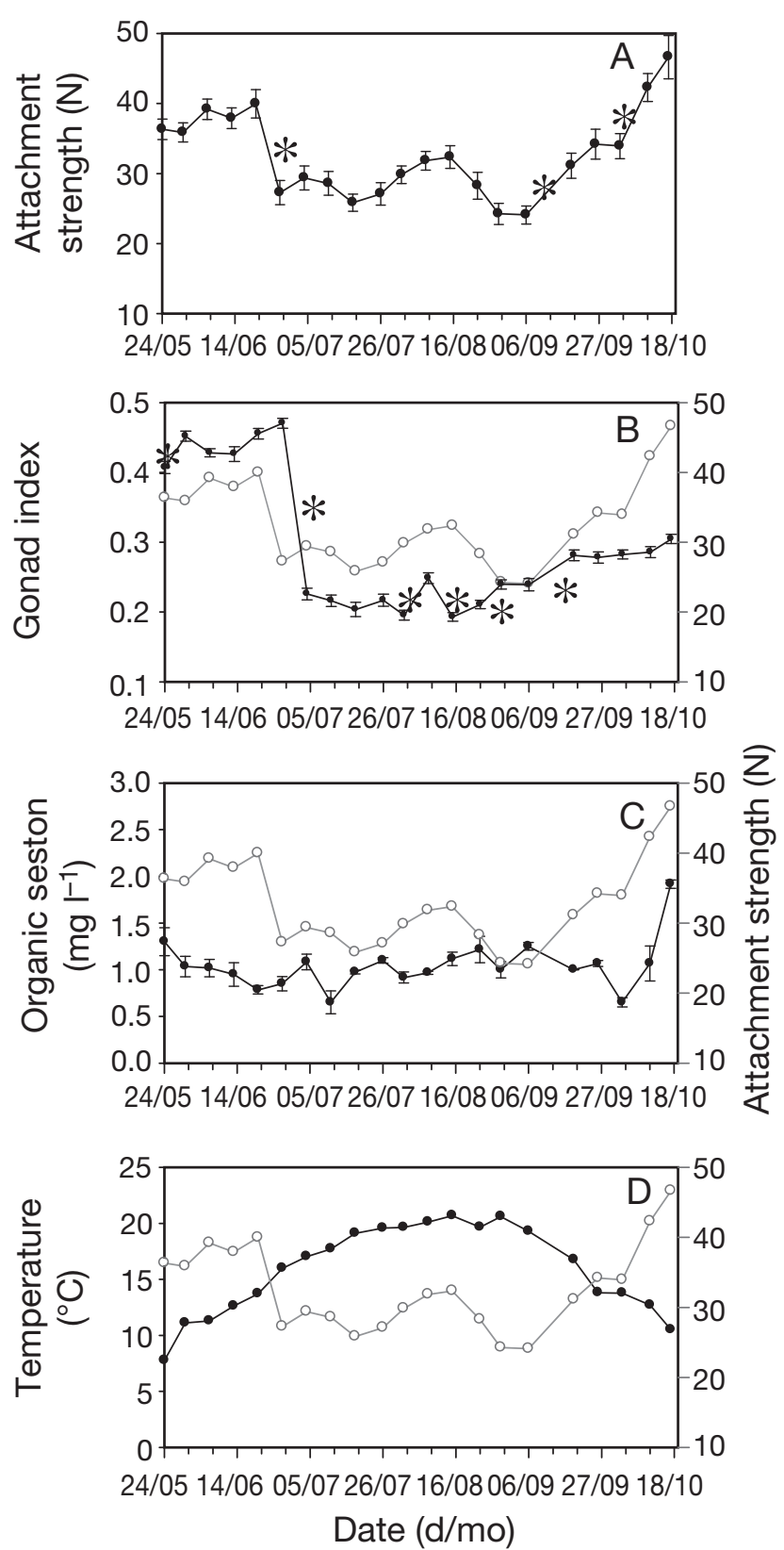

Table 4. Results of forward stepwise multiple regression with attachment strength as the response variable and temperature, wind velocity and gonad index as explanatory variables in 2004; adjusted $\mathrm{R}^{2}=0.607 ; \mathrm{n}=15$

\begin{tabular}{|lccc|}
\hline $\begin{array}{l}\text { Regression } \\
\text { step no. }\end{array}$ & $\begin{array}{l}\text { Source of } \\
\text { variance }\end{array}$ & $\begin{array}{c}\text { Standard } \\
\text { coefficient }\end{array}$ & $\mathrm{p}$ \\
\hline 1 & Temperature & -0.835 & 0.001 \\
2 & Wind velocity & -0.396 & 0.043 \\
\hline
\end{tabular}
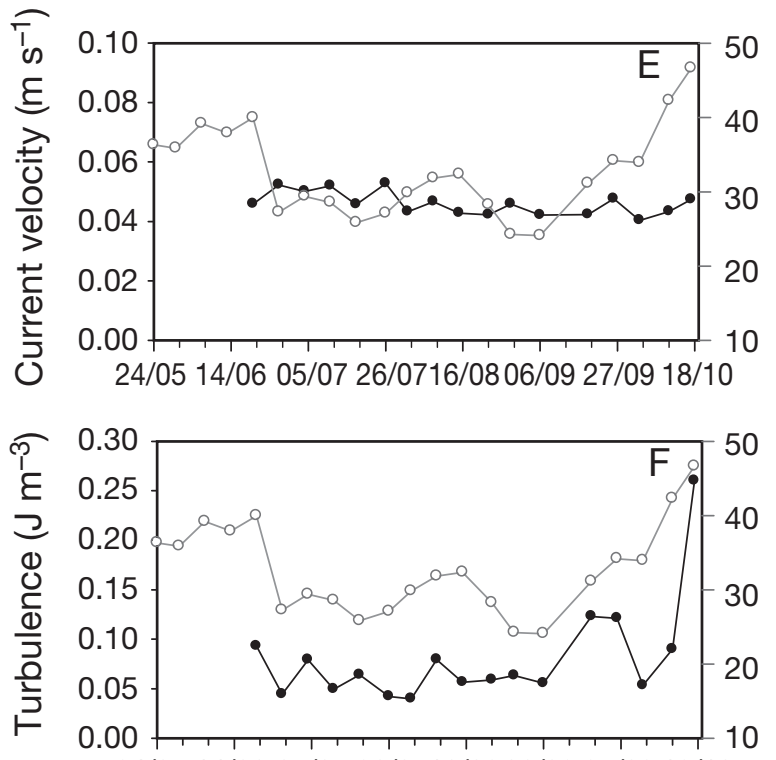

24/05 14/06 05/07 26/0716/0806/09 27/09 18/10
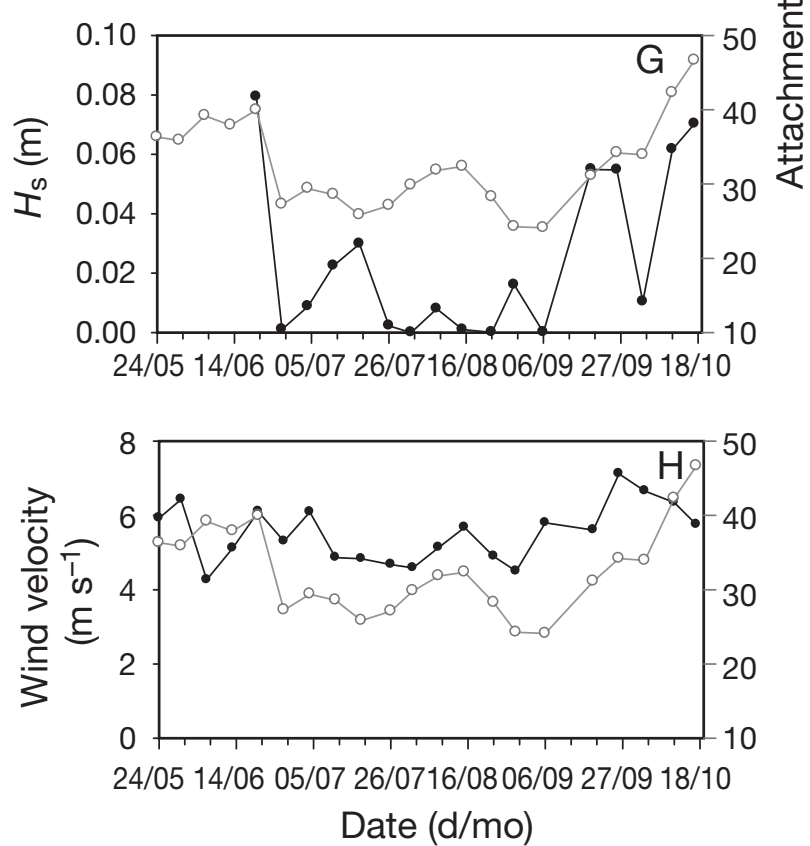

Fig. 4. Mytilus edulis. Weekly values measured in 2005: (A) attachment strength (mean \pm SE), (B) gonad index (mean \pm SE), (C) organic seston (mean $\pm \mathrm{SE})$, (D) water temperature, $(\mathrm{E})$ current velocity, $(\mathrm{F})$ turbulence, $(\mathrm{G})$ significant wave height $\left(H_{\mathrm{s}}\right)$, and $(\mathrm{H})$ wind velocity. An asterisk between 2 successive dates indicates a significant difference revealed by planned comparisons using a $t$-test followed by a Bonferroni correction. Attachment strength data $(\mathrm{O})$ are superimposed in $(\mathrm{B})$ to $(\mathrm{H})$ to facilitate comparisons 
over, the proportion of the variation explained by temperature was more important than that explained by the wind velocity $(6.2 \%)$.

\section{5}

The attachment strength of Mytilus edulis varied considerably and significantly during the sampling period in 2005 (Fig. 4A, Table 5); it was high in late May to early June and decreased quickly and significantly ( $32 \%$ decrease, from 40.0 to $27.3 \mathrm{~N}$ ) in late June ( $p<0.001$ between 20 and 27 June; Fig. 4A). Throughout the summer, the attachment strength remained relatively weak, with no significant differences between 2 successive dates until the beginning of September, after which attachment strength increased steadily (from 24.1 to $46.6 \mathrm{~N}$ ) until the end of the sampling period.

The strength of individual byssal threads was measured in summer (2 August) and in fall (17 October), when mussel attachment strength was weak and strong, respectively. The force needed to break the individual threads was significantly different $\left(t_{16}=\right.$ $3.61, \mathrm{p}=0.001$ ) between the 2 periods, with threads almost $52 \%$ stronger in the fall $(0.50 \mathrm{~N})$ than in the summer $(0.33 \mathrm{~N})$.

Reproductive condition, characterized by the gonad index, also varied significantly during the sampling period (Table 5). The gonad index decreased significantly, from 0.47 to 0.22 , at the end of June, which is a $53 \%$ reduction $(\mathrm{p}<0.001$ between 27 June and 4 July; Fig. 4B). The gonad index remained low all summer and increased slowly in the fall until the end of the sampling period.

The organic seston showed an overall significant variation during the sampling period, but with no particular pattern other than an increase at the beginning of October (Table 6, Fig. 4C). The mean weekly temperature in the lagoon ranged from 8 to $21^{\circ} \mathrm{C}$, with the highest values in July to August, when attachment

Table 5. Hierarchical ANOVAs measuring the differences between dates in 2005 for attachment strength (AS) and gonad index $(\mathrm{GI}) ; \mathrm{n}=630$; AS and GI were log transformed

\begin{tabular}{|c|c|c|c|c|}
\hline Source & df & MS & $F$ & $\mathrm{p}$ \\
\hline \multicolumn{5}{|c|}{ Attachment strength } \\
\hline Date & 20 & 1.076 & 5.974 & $<0.001$ \\
\hline Sleeve (Date) & 42 & 0.180 & 2.286 & $<0.001$ \\
\hline Error & 567 & 0.079 & & \\
\hline \multicolumn{5}{|l|}{ Gonad index } \\
\hline Date & 20 & 6.390 & 113.467 & $<0.001$ \\
\hline Sleeve (Date) & 42 & 0.056 & 1.150 & 0.244 \\
\hline Error & 567 & 0.049 & & \\
\hline
\end{tabular}

strength was low (Fig. 4D). Current velocity was weak during the sampling period and showed no marked variations (values between 4 and $6 \mathrm{~cm} \mathrm{~s}^{-1}$ ) (Fig. 4E). Both turbulence and $H_{\mathrm{s}}$ were low in the summer and increased sporadically from the beginning of September (Fig. 4F,G). The $H_{\mathrm{s}}$ values were sometimes zero, because this parameter was recorded near the bottom of the lagoon: small waves did not reach the bottom and were not recorded (Fig. 4G). The wind velocity, independent of direction, did not show any particular pattern except an increase in September (Fig. 4H).

The relationship between each factor and mussel attachment strength was measured by simple Pearson correlations (Table 7). All factors except the organic seston concentration, wind velocity and current velocity were significantly correlated to the attachment strength. Temperature was the factor with the strongest relationship to attachment strength, and the 2 factors were inversely related. Turbulence was highly and positively correlated to attachment strength, followed by significant correlations with wave height and the gonad index.

A first stepwise multiple regression analysis was done with all factors (temperature, turbulence, gonad index, $H_{\mathrm{s}}$, wind velocity, current velocity and organic seston). This analysis did not include the first 4 experimental weeks due to missing data for turbulence, wave height and current velocity (Table 8 ). This procedure stopped at the first step, with temperature retained as the only significant factor, accounting for $65.5 \%$ of the variability in attachment strength (Table 8 ). This result was explained by the observed inverse pattern between temperature and attachment strength (Fig. 4D).

Table 6. One-way ANOVA for organic seston differences between dates in 2005; $\mathrm{n}=63$

\begin{tabular}{|lcccc|}
\hline Source & df & MS & $F$ & $p$ \\
\hline Date & 20 & 0.220 & 7.985 & $<0.001$ \\
Error & 42 & 0.028 & & \\
\hline
\end{tabular}

Table 7. Simple Pearson correlations relating the attachment strength of mussels with each explanatory factor in 2005. n: number of weekly measurements; $\mathrm{r}^{2}$ : coefficient of determination. Turbulence, significant wave height $\left(H_{\mathrm{s}}\right)$, gonad index and organic seston were log transformed

\begin{tabular}{|lcrr|}
\hline Factor & $\mathrm{n}$ & \multicolumn{1}{c|}{$\mathrm{r}^{2}$} & \multicolumn{1}{c|}{$\mathrm{p}$} \\
\hline Temperature $\left({ }^{\circ} \mathrm{C}\right)$ & 21 & -0.62 & $<0.001$ \\
Turbulence $\left(\mathrm{J} \mathrm{m}^{-3}\right)$ & 17 & 0.52 & 0.001 \\
$H_{\mathrm{s}}$ & 17 & 0.31 & 0.024 \\
Gonad index & 21 & 0.29 & 0.012 \\
Organic seston $\left(\mathrm{mg} \mathrm{l}^{-1}\right)$ & 21 & 0.08 & 0.225 \\
Current velocity $\left(\mathrm{m} \mathrm{s}^{-1}\right)$ & 17 & -0.02 & 0.598 \\
Wind velocity $\left(\mathrm{m} \mathrm{s}^{-1}\right)$ & 21 & 0.14 & 0.087 \\
\hline
\end{tabular}


Table 8. Forward stepwise multiple regression (regress) analyses done with attachment strength as the response variable and all the factors as explanatory variables (Regress No. 1) and all the factors except temperature (Temp) as explanatory variables (Regress No. 2 ) in $2005 ; \mathrm{n}=17$. Turb: turbulence

\begin{tabular}{|lcccccc|}
\hline $\begin{array}{l}\text { Regress } \\
\text { no. }\end{array}$ & Factors & $\begin{array}{c}\text { Regress } \\
\text { step no. }\end{array}$ & $\begin{array}{c}\text { Source of } \\
\text { variance }\end{array}$ & $\begin{array}{c}\text { Adjusted } \\
\mathrm{R}^{2}\end{array}$ & $\begin{array}{c}\text { Partial } \\
\mathrm{r}^{2}\end{array}$ & $\mathrm{p}$ \\
\hline 1 & All factors & 1 & Temp & 0.655 & 0.676 & $<0.001$ \\
2 & Without Temp & 1 & Turb & 0.491 & 0.523 & 0.001 \\
\hline
\end{tabular}

difference in byssal thread strength between summer $(0.12 \mathrm{~N})$ and fall $(0.08 \mathrm{~N})$ for Mytilus edulis from Narragansett Bay (RI, USA). However, individual threads were strongest in spring, which followed the seasonal pattern of attachment strength. It is unknown what specific factors contribute to these changes.

In addition to water temperature, the most influential factors on attachment strength in field conditions were water As collinearity was found between temperature and turbulence, gonad index, and wind velocity (Table 1), the analysis was performed again, but without temperature. In this second multiple regression analysis, turbulence was the only variable introduced into the model, and it explained $49.1 \%$ of the variation in attachment strength (Table 8). When the stepwise analysis was forced to enter 2 factors in the model, gonad index was the only other factor to be included in the model, but it was not significant $(\mathrm{p}=0.20)$.

\section{DISCUSSION}

There was a strong variation in the attachment strength in suspended cultured mussels Mytilus edulis between spring and fall in the sheltered lagoon, with a significant decrease in June, followed by low levels all summer and a 2-fold increase in September to October. Similar variations in attachment strength of wild mussels, following a seasonal cycle, have also been observed on Rhode Island shores (Carrington 2002a, Moeser \& Carrington 2006), in Nova Scotia (Hunt \& Scheibling 2001), in the UK (Price 1982), and in South Africa (Zardi et al. 2007). Carrington (2002a) found a pattern similar to that observed in our study, with values of tenacity (attachment strength/platform area) increasing 2-fold in fall/winter relative to summer. Although the present study covered a shorter period $\left(<6 \mathrm{mo} \mathrm{yr}^{-1}\right)$, it is unique for its higher sampling frequency compared to previous studies (i.e. weekly rather than monthly samplings). This higher sampling frequency provided a more precise picture of attachment strength transitions between the seasons: the spring decline in strength was sharp, while the fall increase was more gradual.

Mussel attachment strength is not only related to the number of byssal threads, but also to the strength of each individual thread (Smeathers \& Vincent 1979, Bell \& Gosline 1996, 1997). We observed that the maximum force needed to break an individual thread varied seasonally: threads produced in fall were $52 \%$ stronger than in summer ( 0.50 vs. $0.33 \mathrm{~N}$, respectively). Moeser \& Carrington (2006) did not find a significant turbulence (hydrodynamic conditions) and mussel reproductive condition. Temperature seems to be the most influential factor on attachment strength because of its strong negative correlation $\left(\mathrm{r}^{2}=-0.52\right.$ in 2004 and -0.62 in 2005). This parameter is the only factor retained in the forward stepwise multiple regression model, explaining $60.2 \%$ of the variability in attachment strength in 2004 and $65.5 \%$ in 2005 . The temperature varied between 8 and $21^{\circ} \mathrm{C}$ during the sampling period, with higher values in the summer, when attachment strength was weak, and lower values in the late spring and fall, when attachment strength was high. This inverse relationship between temperature and attachment strength is in accordance with Carrington (2002a) for Mytilus edulis in Rhode Island. However, these results should to be interpreted with caution. First, Price (1982) observed the opposite pattern, with a positive correlation between attachment strength of $M$. edulis and temperature on the shores in England, where temperatures mostly varied between 10 and $15^{\circ} \mathrm{C}$, with a maximum value of $17^{\circ} \mathrm{C}$ in September. Furthermore, a number of laboratory studies showed that the production of byssal threads increases with temperature within a range of 5 to $25^{\circ} \mathrm{C}$ (Young 1985, Selin \& Vekhova 2004, Kobak 2006). This positive relationship between temperature and attachment strength (more byssal threads = higher attachment strength) was not evident in this field study, perhaps because thread decay is higher in the summer when temperatures are warmer (Moeser \& Carrington 2006). Thus, temperature could possibly have a direct negative effect on attachment strength through a higher rate of thread decay than thread production.

When a forward stepwise multiple regression was performed without temperature as an explanatory variable, water turbulence became the most important factor acting on attachment strength, explaining $50 \%$ of its variability. This is due to the high correlation between turbulence and attachment strength $\left(\mathrm{r}^{2}=\right.$ 0.52). Turbulence is a hydrodynamic parameter characterizing the water column and is defined as fluid particles moving in a highly irregular manner with intense small-scale, 3-dimensional motion (Vogel 1989, Mann \& Lazier 2006). It has also been suggested 
that water motion has an important influence on the attachment strength of wild mussels on wave-swept shores (Price 1982, Witman \& Suchanek 1984, Bell \& Gosline 1997, Hunt \& Scheibling 2001, 2002, Carrington 2002a,b). This positive relationship was also observed in the laboratory, with an increase in water agitation or flow velocity triggering thread production and an increase in mussel attachment strength (Witman \& Suchanek 1984, Young 1985, Lee et al. 1990, Dolmer \& Svane 1994, Alfaro 2005). However, Moeser et al. (2006) observed an inverse relationship, with increased flow generated in a flume consistently reducing thread production. As suspension-cultured mussels in the present study were kept $2 \mathrm{~m}$ below the surface, it is likely that hydrodynamic parameters in the lagoon do not influence the attachment strength of mussels in the same way as they do in the intertidal zone. However, based on past observations (Koutitonsky et al. 2002), turbulence is the hydrodynamic parameter the most likely to influence mussel attachment strength in the well-mixed water column of this shallow lagoon.

Reproductive condition is another factor that seemed to have an important influence on the attachment strength of cultured mussels. This factor, as revealed by the gonad index, was significantly correlated to attachment strength in $2005\left(\mathrm{r}^{2}=0.29\right)$. Indeed, a massive spawning event, as shown by a $53 \%$ decrease in the gonad index over a single week (from 0.47 to 0.22 ), occurred almost simultaneously (during the following week), with a drastic decline in attachment strength $(-32 \%)$ in late June to early July 2005 . This is the usual period of mass spawning for suspension-cultured mussels in eastern Canada (Mallet \& Myrand 1995), and similar decreases in the gonad index are in agreement with reported losses of up to $50 \%$ of total wet weight that have been reported following spawning (Kautsky 1982, Mallet \& Myrand 1995). This dramatic decline in the gonad index at the end of June was not apparent in 2004, most likely because sampling started 1 mo later than in 2005, probably after the mass spawning. This explains the lack of correlation between the gonad index and attachment strength in $2004\left(\mathrm{r}^{2}=0.20\right)$. Reproductive condition was not retained in the multiple regression model, possibly because there was a $1 \mathrm{wk}$ lag between the decreases in attachment strength and the gonad index in 2005. Furthermore, the multiple regression analysis did not include the results from the first $4 \mathrm{wk}$ of the sampling period, when both the gonad index and the attachment strength showed high values, because data on hydrodynamic parameters were lacking. However, when the probability threshold was set at $\mathrm{p}=0.20$ in the multiple regression, the only factor added with turbulence in the model was the gonad index.
Although reproduction requires a high energy input for gamete production (Bayne et al. 1983, Lemaire et al. 2006), it did not negatively influence the attachment strength of cultured mussels as has been shown in other studies with wild mussels (Carrington 2002a, Zardi et al. 2007). Indeed, mussels can allocate as much as $90 \%$ of their energy to gamete production (Rodhouse 1984, Seed \& Suchanek 1992), while byssal thread production can represent $8 \%$ of a mussel's monthly energy expenditure (Hawkins \& Bayne 1985). When available energy is limited, allocation is divided between competing physiological functions: metabolism, growth, gamete production and byssal thread production (Bayne \& Newell 1983). Some studies on wild mussels reported a trade-off between gamete production and attachment strength (Carrington 2002a, Zardi et al. 2007). These authors hypothesized that byssal thread production may only be possible when energy is available, i.e. when there is no gamete production. However, there is no such trade-off in our study: attachment strength was high during the $4 \mathrm{wk}$ preceding the mass spawning, i.e. during the last phase of gametogenesis. Furthermore, attachment strength was weak in the summer during the resting period that follows spawning. It is possible that the differences in hydrodynamic and temperature conditions between wild mussels on rocky shores and cultured mussels in suspension explain these differences. Wild mussels experience potentially more extreme water turbulence and temperatures. We can also hypothesize that the available energy (food quantity and quality) was not limited for suspended cultured mussels, which are always submerged during gametogenesis, so that byssal thread production could occur concurrently with gametogenesis with no need for trade-offs. Moreover, gametogenesis occurred in early summer, when temperature was not at its peak, so thread decay is probably low (Carrington 2002a).

The major decrease in attachment strength occurred rapidly and almost simultaneously with the massive spawning. To our knowledge, no other studies have reported such synchrony between a sharp decrease in attachment strength and spawning. As thread decay usually takes about 4 to 6 wk (Carrington 2002a, Moeser \& Carrington 2006), this sharp decline in attachment strength within 1 wk suggests that many threads were lost during a short period near or during spawning. Mussels may sever or jettison their own byssal threads (Price 1983, Lee et al. 1990, Hunt \& Scheibling 2002), or thread decay was accelerated at this time. After having invested large amounts of energy in gamete production, spawning is known to be a stressful event that can weaken mussels and even lead to massive mortality (Mallet \& Myrand 1995, Myrand et al. 2000). For example, cells of the digestive 
tubules of mussels show disruption of their structure and evidence of autolysis after spawning (Bayne et al. 1978). This could decrease their ability for food absorption and thus limit their energy intake. As a result, less energy could be available for the production of new byssal threads for a certain period of time after spawning, thus contributing to low attachment strength at this time.

Food concentration had no significant influence on attachment strength. Organic seston concentration showed no particular cycle, with values relatively stable $\left(\sim 1 \mathrm{mg} \mathrm{l}^{-1}\right)$ during the sampling period, except for an increase (up to $2 \mathrm{mg} \mathrm{l}^{-1}$ ) in fall, probably corresponding to a phytoplankton bloom. These values are in agreement with typical values found in lagoons of the Magdalen Islands (Mallet \& Myrand 1995). Food availability is known to influence byssal thread production, since starved mussels decrease their thread production (Price 1980, Young 1985, Clarke 1999). In contrast to results in these studies, the increase in the organic seston concentration in October occurred after the attachment strength began to increase (September) in the lagoon. Thus, food availability, measured by organic seston, was not a major factor driving the variation of attachment strength of cultured mussels at the experimental site. This may be the result of low variability in the seston concentration during the sampling period. However, diet quality (biochemical characteristics) could influence mussel attachment. We know that the water column in the Magdalen Islands is dominated by heterotrophic protists (mostly ciliates) and that phytoplankton is dominant only for a short period (Trottet et al. 2007). Microzooplankton can constitute a food source for mussels (Lehane \& Davenport 2006), but the biochemical composition of this food could influence the mussels' energetic allocation. As discussed earlier, the force needed to break individual byssal threads changed seasonally in the present study and did not seem to be related to food concentration. In fact, Monahan \& Wilker (2004) suggested that factors influencing the material properties of byssal threads are present in the water chemistry rather than in food.

The low current velocities measured in the lagoon had no impact on attachment strength. Throughout the sampling period, current velocity varied only between 4 and $6 \mathrm{~cm} \mathrm{~s}^{-1}$ where the mussel sleeves were held in suspension. This is in agreement with previous measurements of current velocity $\left(<5 \mathrm{~cm} \mathrm{~s}^{-1}\right)$ in this lagoon (Koutitonsky et al. 2002). Dolmer \& Svane (1994) showed no difference in thread production between still water and currents of $7.7 \mathrm{~cm} \mathrm{~s}^{-1}$, but production increased at $19.4 \mathrm{~cm} \mathrm{~s}^{-1}$. Current velocity was not correlated to attachment strength, probably because velocities were weak and showed very little variation.
Wave action, which was estimated by $H_{\mathrm{s}}$, was significantly correlated to attachment strength. As discussed above, wave action is a dominant factor in the intertidal environment and enhances thread production (Price 1982, Witman \& Suchanek 1984, Bell \& Gosline 1997, Carrington 2002a). However, attachment strength was more strongly correlated to turbulence than to $H_{\mathrm{s}}$ even though both are mostly the result of wind action (Open University 1989, Kjerfve 1994, Mann \& Lazier 2006). Wave action probably does not influence wild mussels in the intertidal zone in the same way it does the suspension-cultured mussels. Cultured mussels are kept suspended in the water column and are thus primarily influenced by turbulence rather than by the wave height. Wave action may also have been underestimated in our study because waves were recorded near the bottom of the lagoon ( $6 \mathrm{~m}$ from the surface) and thus were smaller than at the sleeve depth $(2 \mathrm{~m}$ from the surface).

In conclusion, this is the first study to examine the attachment strength of suspension-cultured mussels showing 2-fold variations from summer to fall and a mass spawning occurring almost synchronously with a major decrease in attachment strength. Furthermore, turbulence seemed to positively influence the attachment strength of mussels after the massive spawning in early summer.

Acknowledgements. We thank the staff of the Centre maricole des Îles de la Madeleine as well as P. Bourret and S. Belvin for their field support. S. Leblanc and G. Desmeules were very helpful in providing and analyzing the environmental data. We appreciate the helpful advice provided by A. Caron on statistical analyses. We thank G. Moeser for her constant help at Friday Harbor Laboratories, M. Fournier for providing mussel sleeves, and L. Devine for linguistic revision. Finally, we are grateful to the Réseau Aquacole du Québec (RAQ), the Ministère des Pêches et Océans Canada (MPO), the Programme Coopératif de Recherche et Développement en Aquaculture (PCRDA), the Société de Développement de l'Industrie Maricole (SODIM) and the Ministère de l'Agriculture, des Pêcheries et de l'Alimentation du Québec (MAPAQ) for their financial support.

\section{LITERATURE CITED}

Alfaro AC (2006) Byssal attachment of juvenile mussels, Perna canaliculus, affected by water motion and air bubbles. Aquaculture 255:357-361

Aminot A, Chaussepied M (1983) Manuel des analyses chimiques en milieu marin. Centre national pour l'exploitation des océans, Paris

Bayne BL, Newell RC (1983) Physiological energetics of marine molluscs. In: Saleuddin ASM, Wilbur KM (eds) The Mollusca, Vol 4. Physiology, Part 1. Academic Press, New York, p 407-513

Bayne BL, Holland DL, Moore MN, Lowe DM, Widdows J (1978) Further studies on the effects of stress in the adult on the eggs of Mytilus edulis. J Mar Biol Assoc UK 58: $825-841$ 
Bayne BL, Salkeld PN, Worrall CM (1983) Reproductive effort and value in different populations of the marine mussel, Mytilus edulis L. Oecologia 59:18-26

Bell EC, Denny MW (1994) Quantifying wave exposure-A simple device for recording maximum velocity and results of its use at several field sites. J Exp Mar Biol Ecol 181: 9-29

Bell EC, Gosline JM (1996) Mechanical design of mussel byssus: material yield enhances attachment strength. J Exp Biol 199:1005-1017

Bell EC, Gosline JM (1997) Strategies for life in flow: tenacity, morphometry, and probability of dislodgement of two Mytilus species. Mar Ecol Prog Ser 159:197-207

Bourque F, Myrand B (2006) Étude descriptive du dégrappage en milieu lagunaire aux Îles-de-la-Madeleine. Rapport de R-D No. 152, MAPAQ, DIT, Gaspé

Brazee SL, Carrington E (2006) Interspecific comparison of the mechanical properties of mussel byssus. Biol Bull 211:263-274

Carrington E (2002a) Seasonal variation in the attachment strength of blue mussels: causes and consequences. Limnol Oceanogr 47:1723-1733

Carrington E (2002b) The ecomechanics of mussel attachment: from molecules to ecosystems. Integr Comp Biol 42:846-852

Clarke M (1999) The effect of food availability on byssogenesis by the zebra mussel (Dreissena polymorpha Pallas). J Molluscan Stud 65:327-333

Dolmer P, Svane IB (1994) Attachment and orientation of Mytilus edulis L. in flowing water. Ophelia 40:63-74

- Hawkins AJS, Bayne BL (1985) Seasonal variation in the relative utilization of carbon and nitrogen by the mussel Mytilus edulis: budgets, conversion efficiencies and maintenance requirements. Mar Ecol Prog Ser 25:181-188

> Hunt HL, Scheibling RE (2001) Predicting wave dislodgment of mussels: variation in attachment strength with body size, habitat, and season. Mar Ecol Prog Ser 213:157-164

Hunt HL, Scheibling RE (2002) Movement and wave dislodgment of mussels on a wave-exposed rocky shore. Veliger 45:273-277

Kautsky N (1982) Quantitative studies on gonad cycle, fecundity, reproductive output and recruitment in a Baltic Mytilus edulis population. Mar Biol 68:143-160

Kjerfve B (1994) Coastal lagoon processes. Elsevier Oceanography Series 60, Elsevier Science Publishers, Amsterdam

Kobak J (2006) Factors influencing the attachment strength of Dreissena polymorpha (Bivalvia). Biofouling 22:141-150

Koutitonsky VG, Tita G (2006) Temps de renouvellement des eaux dans la lagune de Grande-Entrée aux Iles-de-laMadeleine. Cahier d'information No. 151, Ministère de l'Agriculture, des Pêcheries et de l'Alimentation du Québec, Gaspé

Koutitonsky VG, Navarro N, Booth D (2002) Descriptive physical oceanography of Great-Entry Lagoon, Gulf of St. Lawrence. Estuar Coast Shelf Sci 54:833-847

Lee CY, Lim SSL, Owen MD (1990) The rate and strength of byssal reattachment by blue mussels (Mytilus edulis L). Can J Zool 68:2005-2009

Lehane C, Davenport J (2006) A 15-month study of zooplankton ingestion by farmed mussels (Mytilus edulis) in Bantry Bay, Southwest Ireland. Estuar Coast Shelf Sci 67:645-652

Lemaire N, Pellerin J, Fournier M, Girault L, Tamigneaux E, Cartier S, Pelletier E (2006) Seasonal variations of physiological parameters in the blue mussel Mytilus spp. from farm sites of eastern Quebec. Aquaculture 261:729-751

Editorial responsibility: Peter Beninger,

Nantes, France
Mallet A, Myrand B (1995) The culture of the blue mussel in Atlantic Canada. In: Boghen AD (ed) Cold water aquaculture in Atlantic Canada, 2nd edn. CIRRD, University of Moncton, Moncton, NB, p 257-298

Mann KH, Lazier JRN (2006) Dynamics of marine ecosystems: biological-physical interactions in the oceans, 3rd edn. Blackwell Publishing, Dartmouth, NS

Moeser GM, Carrington E (2006) Seasonal variation in mussel byssal thread mechanics. J Exp Biol 209:1996-2003

Moeser GM, Leba H, Carrington E (2006) Seasonal influence of wave action on thread production in Mytilus edulis. J Exp Biol 209:881-890

> Monahan J, Wilker JJ (2004) Cross-linking the protein precursor of marine mussel adhesives: bulk measurements and reagents for curing. Langmuir 20:3724-3729

Myrand B, Guderley H, Himmelman JH (2000) Reproduction and summer mortality of blue mussels Mytilus edulis in the Magdalen Islands, southern Gulf of St. Lawrence. Mar Ecol Prog Ser 197:193-207

Open University (1989) Waves, tides and shallow-water processes. Open University, Milton Keynes

Price HA (1980) Seasonal variation in the strength of byssal attachment of the common mussel Mytilus edulis. J Mar Biol Assoc UK 60:1035-1037

Price HA (1982) An analysis of factors determining seasonal variation in the byssal attachment strength of Mytilus edulis. J Mar Biol Assoc UK 62:147-155

Price HA (1983) Structure and formation of the byssus complex in Mytilus (Mollusca, Bivalvia). J Molluscan Stud 49: 9-17

Quinn GP, Keough MJ (2002) Experimental design and data analysis for biologists. Cambridge University Press

> Rodhouse PG (1984) Resource allocation in Mytilus edulis on the shore and in suspended culture. Mar Biol 84:27-34

Seed R, Suchanek TH (1992) Population and community ecology of Mytilus. In: Gosline EG (ed) The mussel Mytilus: ecology, physiology, genetics, and culture. Elsevier, Amsterdam, p 87-169

Selin NI, Vekhova EE (2004) Effects of environmental factors on byssal thread formation in some members of the family Mytilidae from the Sea of Japan. Russ J Mar Biol 30: 306-313

Smeathers JE, Vincent JFV (1979) Mechanical properties of mussel byssus thread. J Molluscan Stud 45:219-230

Tremblay R, Myrand B, Sévigny JM (1998) Genetic characterization of wild and suspension-cultured blue mussels (Mytilus edulis Linneaus, 1758) in the Magdalen Islands (southern Gulf of St. Lawrence, Canada). J Shellfish Res 17:1191-1202

> Trottet A, Roy S, Tamigneaux E, Lovejoy C (2007) Importance of heterotrophic planktonic communities in a mussel culture environment: the Grande Entrée lagoon, Magdalen Islands (Québec, Canada). Mar Biol 151:377-392

Vogel S (1989) Life in moving fluids: the physical biology of flow. Princeton University Press, Princeton, NJ

Witman JD, Suchanek TH (1984) Mussels in flow: drag and dislodgment by epizoans. Mar Ecol Prog Ser 16:259-268

> Young GA (1985) Byssus-thread formation by the mussel Mytilus edulis: effect of environmental factors. Mar Ecol Prog Ser 24:261-271

Zardi GI, McQuaid CD, Nicastro KR (2007) Balancing survival and reproduction: seasonality of wave action, attachment strength and reproductive output in indigenous Perna perna and invasive Mytilus galloprovincialis mussels. Mar Ecol Prog Ser 334:155-163

Submitted: October 17, 2007; Accepted: February 28, 2008

Proofs received from author(s): April 11, 2008 